
work is properly cited

\title{
ANTIBODY DRUG CONJUGATES: A LEAP AHEAD IN CANCER TREATMENT
}

\author{
Singh Harsharan Pal ${ }^{1}$, Gullaiya Sumeet ${ }^{1}$, Kaur Ishpreet ${ }^{2}$ \\ ${ }^{1}$ Amity Institute of Pharmacy, Amity University, Noida-201303 (Uttar Pradesh) \\ ${ }^{2}$ Delhi Institute of Pharmaceutical Sciences and Research, Pushp Vihar, New Delhi \\ *Corresponding Author's E-mail id: harsharanpal.singh@gmail.com
}

\begin{abstract}
Monoclonal antibody (MAb) based targeted therapies have achieved appreciable success in various branches of drug therapeutics, predominantly when used along with cytotoxic drugs. These immunological therapies based on antibody-drug conjugates (ADCs) have been recently encouraged by the US Food and Drug Administration to treat Solid tumours, Melanoma, Breast Cancer and Hodgkin's lymphoma. Antibody drug conjugates (ADCs) are an important division of therapeutics that allows the antigen-selective ability of MAbs to deliver highly potent cytotoxic drugs at the site of antigenexpressing tumor cells. The use of MAb directed delivery can confer a high therapeutic index to highly potent cytotoxic drugs, increasing both the efficacy and safety of therapy. In other words, to achieve the goal of highly improved therapeutic efficacy and reduced toxicity, each component of an ADC i.e. the MAb, linker and the drug needs to be considered in context of targeted antigen. Furthermore, the mechanism of ADCs, characteristics of targets, methods of preparation, linker drugs being used in ADC design and regulatory requirements for new drug approval are discussed.

Keywords: Antibody-drug conjugates, Cytotoxic drugs, Monoclonal antibodies, Tumour
\end{abstract}

\section{INTRODUCTION}

Recent advances in oncology have focused on identifying drugs with improved selectivity for malignant cell versus normal cell as means to improve both the efficacy and tolerability of cancer treatment. One approach for enhancing and improving selectivity is to identify therapeutic targets with altered levels of expression on malignant versus normal cells and direct therapy against those targets. The introduction of monoclonal antibody (MAb) technology by Kohler and Milstein in $1975^{1}$ led to thorough efforts to develop MAbs as highly selective antitumor therapeutics; however the immunogenicity of the very first generation, murine MAbs limited their application as therapeutics. The ability to obtain fully human MAbs from transgenic mice and by phage display has further enhanced and elaborated the clinical potential of these approaches ${ }^{2-4}$. There are currently 9 unconjugated MAbs approved by the FDA as cancer therapeutics. These MAbs include 2 chimeric, 4 humanized and 3 fully human monoclonal antibodies that display antitumor activity via blocking ligand/receptor interactions, or induce cell killing by means of antibody dependent cellular cytotoxicity (ADCC), or complement dependent cytotoxicity (CDC) 5. Monoclonal antibodies have also been used to selectively deliver radionuclides ${ }^{6,7}$, plant and bacterial toxins, ${ }^{8-10}$ and a large variety of cytotoxic drugs ${ }^{11-14}$. $\mathrm{MAb}$ directed delivery of cytotoxic drugs is an area of intense and keen interest and there are currently at least 25 antibody drug conjugates (ADCs) undergoing clinical evaluation in oncology.

\section{CHARACTERISTICS OF ANTIBODY DRUG CONJUGATES (ADC'S)}

Antibody drug conjugates comprises of a MAb chemically coupled to a linker and a cytotoxic drug (Figure1). Mechanistically, ADCs are developed to be stable in circulation and to effect intracellular drug release followed by antigen-specific binding and internalization of the ADC. Currently the designing of ADCs as therapeutics has been focusing almost exclusively on the treatment of cancer. In contrast to small molecule cancer agents or function blocking MAbs, the targets for ADCs do not need to be causal in tumor progression. Rather those target antigens need to be most differentially expressed on the cell surface of malignant cells relative to normal tissues. The MAbs employed in first generation ADCs have identified cell surface antigens with different levels of tumor selectivity and also included MAbs that internalized following antigen binding and those that did not. To be highly effective, non-internalizing ADCs needed to remain intact into the circulation i.e. not release the hold of drug before reaching the target site and yet selectively release active drug at the tumor specific site. Typically, these ADCs made use of peptidyl linkers which were designed to be cleaved by enzymes like cathepsins and matrix metalloproteinases expressed dominantly at the tumor site, or linkers that would be releasing the drug by hydrolysis at a slightly acidic $\mathrm{pH}$ as observed in many solid tumors. 
For most of the part, these non-internalizing ADCs did not show much significant antigen-specific activity and did not significantly improve the therapeutic index (maximum tolerated dose/active dose) in contrast to that of the free drug ${ }^{15,16}$. The use of the MAbs that cause internalization following antigen binding has led to the designing of linkers that are stable in circulation and efficiently release the active drug following antigen specific binding, internalization and trafficking to endosomes/lysosomes ${ }^{17-19}$. Internalizing of ADCs has demonstrated a highly impressive preclinical ${ }^{20-23}$ and clinical $^{24-29}$ activity.

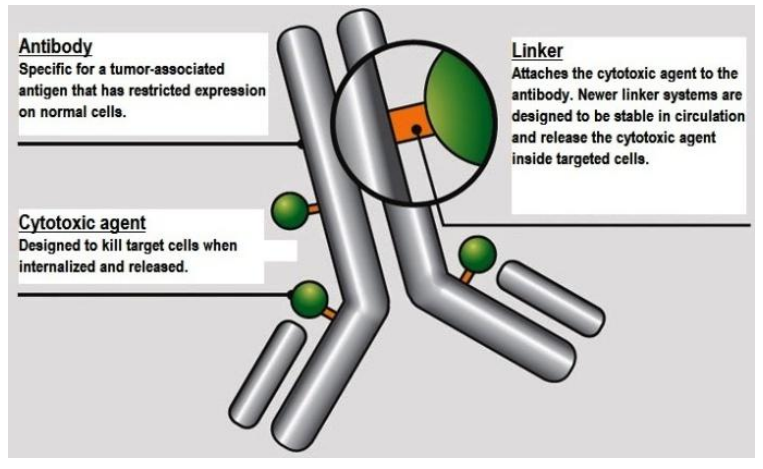

Figure 1: Schematic illustrating an Antibody Drug Conjugate (ADC)

\section{ADCS: PHARMACOKINETIC VERSUS CHEMOTHERAPY \\ ADVANTAGE}

Traditional chemotherapy employs potent small molecules to destroy rapidly dividing cells, often through antimitotic or DNA-hampering mechanisms. Systemic administration of these drugs results in not only tumor killing and also damaging the healthy cells. The balance between these 2 actions plays a limiting factor in the efficacy and tolerability of single-agent chemotherapy. As a result, most of the cancer regimens consist of combinations of chemotherapeutic agents, each one of them administered at or near the maximum tolerated dose and for a very limited duration due to their uptake and leading to cumulative damage to normal tissues ${ }^{30}$. The rapid clearance of these small molecules and increase in hydrostatic pressure in the solid tumors has further decreased the tumor-specific activity of chemotherapy. In contrast, monoclonal antibodies, are large molecules (150 kDalton) that can be effectively retained in the vasculature for about several weeks and slowly diffuse into the perivascular tissue ${ }^{31,32}$.The complementarity-determining regions can efficiently provide high-affinity binding which is directed against cell-surface antigens on tumor cells. The combination of a long half-life, specificity for tumor cells and high binding affinity results in the accumulation of antibody at the tumor site over a period of time. The lack of direct and serious cytotoxicity often facilitates prolonged treatment that is well tolerated and relatively safe. However, most monoclonal antibodies have very limited single-agent activity against cancer cells and are frequently used in combination with chemotherapy. Despite of a long time of active research and development, only 9 naked antibodies directed at 6 molecular targets have currently been approved by the US Food and Drug Administration (US-FDA) for cancer therapy (Table 1) ${ }^{31}$. ADCs are fabricated to take advantage of both the potent cell-killing activities of small molecules and the pharmacokinetic and biodistribution potential of monoclonal antibodies. ${ }^{19}$ ADCs have empowered antibodies by chemically conjugating a cytotoxic payload that can be effectively deliver and release that cytotoxic drug at the tumor while limiting systemic exposure to the cytotoxic agent. The proposed mechanisms of action for an ADC include; antibody engagement with a cell-surface target on cancerous cells, internalization and intracellular accumulation of the intact macromolecule to the lysosomes, rapidly releasing of the cytotoxic agent, and finally leading to efficient degeneration of tumor cells.

Table 1: Unconjugated monoclonal antibodies approved for cancer

\begin{tabular}{|c|c|c|c|}
\hline Target & Antibody & Therapeutic Indication & First US Approval \\
\hline CD20 & Rituximab & NHL & 1997 \\
\hline CD20 & Ofatumumab & CLL & 2009 \\
\hline Her2 & Trastuzumab & Breast Cancer & 1998 \\
\hline Her2 & Pertuzumab & Breast Cancer & 2012 \\
\hline CD52 & Alemtuzumab & CLL & 2001 \\
\hline EGFR & Cetuximab & Colon Cancer & 2004 \\
\hline EGFR & Panitumumab & Colon Cancer & 2006 \\
\hline VEGF & Bevacizumab & Colon Cancer & 2004 \\
\hline CTLA-4 & Ipilimumab & Melanoma & 2011 \\
\hline
\end{tabular}

There are specifically 5 important elements in the designing of effective ADCs: (1) The Molecular Target; (2) The Delivery Vehicle (monoclonal antibody or alternative scaffold); (3) Chemical Conjugation (method, site, and stoichiometry); (4) The Linker, including the suitable mechanism of drug release; and (5) The Cytotoxic Agent or Payload ${ }^{34,35}$. Current concepts for each of these elements are explicitly addressed in this review.

\section{MECHANISM OF ACTION}

A successful ADC consists of a MAb - a versatile platform for anticancer therapy which is capable of binding to the surface of tumour cell-specific antigens ${ }^{[35]}$. These antigens include over-expressed B-cell surface proteins in non-Hodgkin's lymphoma (NHL) such as CD19, CD20, CD21, CD22, CD40, CD72, CD79b and CD180, extending to the T-cell proteins CD25 and CD30 
of the immune system. Moreover, proteins that are over expressed on carcinoma cells, including the human epidermal growth factor receptor 2 (HER2); prostatespecific membrane antigen (PSMA) and cryptic family protein $1 \mathrm{~B}$ (Cripto) are also antigens. These tumourassociated antigens have been studied as potential treatments for the following oncology indications: leukemia, lymphoma and multiple myeloma ${ }^{36}$. The function of cytotoxic drugs (e.g. auristatins, maytansinoids and calicheamicins), are designed to induce tumour cell death, by causing irreversible DNA damage and/or interfering with the mechanism of cell division ${ }^{37}$. The theory behind the mechanism of action of ADCs (Figure 2) involves the following processes: Binding (Stage 1) - The MAb component of the ADC binds to the target antigen on the surface of the tumour cell to produce an ADC-antigen (ADC-CDX) complex, which is engulfed into a clathrin-coated vesicle; Clathrin-Mediated Endocytosis (Stage 2) - This binding then initiates a cascade of events, involving the internalization of the ADC-antigen clathrin coated vesicle into the tumour cell. Consequently, the vesicle loses its coat and enables the ADC-antigen complex to fuse with an early sorting endosome, to initiate the release of the antigen from the ADC. At this stage, the antigen may be recycled back to the cell membrane. Furthermore, the early endosome converts to a late endosome containing the ADC; Degradation (Stage 3) The internalized ADC is transported through the late endosome pathway to the intracellular compartment of a lysosome, where it is degraded to release the cytotoxic drug. The cleavable linkers rely on processes inside the cell to liberate the cytotoxic drug such as reduction of disulfide bonds mediated by glutathione (GSH) in the cytoplasm, exposure to acidic conditions $(\mathrm{pH} \sim 4)$ in the lysosome, or cleavage by specific proteases within the cell. Conversely, non-cleavable linkers require catabolic degradation ${ }^{38}$ of the Mab, to release the cytotoxic drug retaining the linker and amino acid (lysine) residue, by which it was attached to the MAb; Release (Stage 4) The cytotoxic drug enters the cytoplasm, where it binds to its molecular target. In route $\mathbf{A}$ - calicheamicin based drugs ${ }^{39}$ interact with the minor groove of DNA and in route $\mathbf{B}$-auristatins and maytansinoids disrupt the microtubules ${ }^{40}$. Subsequently, the cytotoxic drug may also pass through the cell membrane and enter other cells in close proximity thereby mediating a bystander killing effect; Stage 5 - Cell Death: The interaction of the cytotoxic drug with DNA and microtubules initiates a chain of events leading to apoptosis ${ }^{41}$.

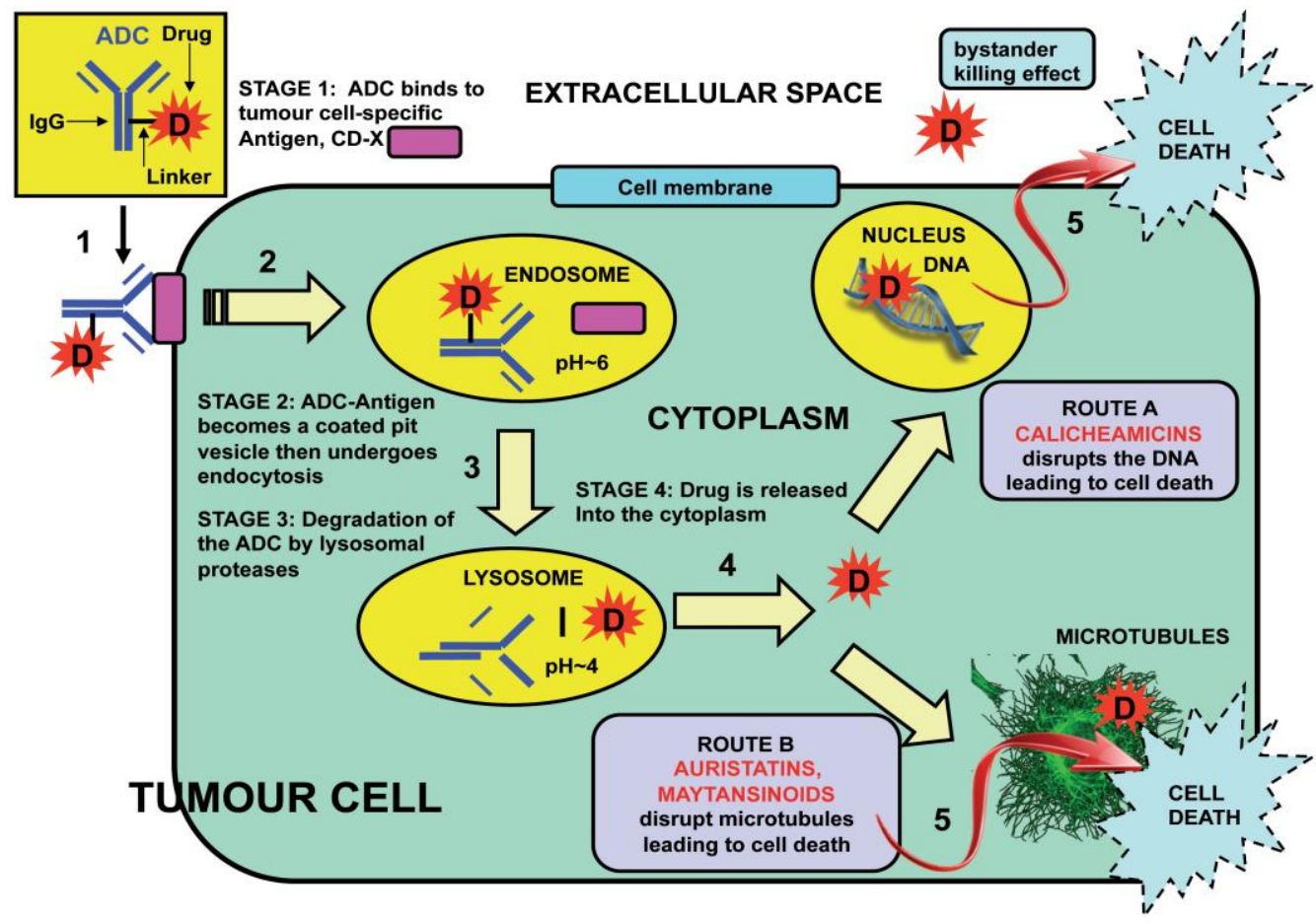

Figure 2: Schematic representation of the ADC-Antigen internalization process

\section{VARIOUS AVAILABLE LINKERS AND DRUGS}

To be sufficiently and desirably effective, an ADC must selectively bind, internalize and deliver an adequate intracellular concentration of drug that is sufficient to result in cell death and cancer cell degeneration (Figure $2)$. While in general, the conjugation strategies and methodologies used in ADC designing should have minimal effects on MAb affinity but still there are limited data available that can be used to define the optimal, or even the minimal, affinity that is required for an effective ADC fabrication. Rather than MAb affinity being the driver of ADC efficacy it is likely that the selectivity, efficiency of internalization and intracellular accumulation of a given $\mathrm{MAb}$ in composite will define an efficacious, potent and safe ADC. The copy number and heterogeneity of antigen expression must be considered in the selection of drug and linker. This is particularly very important for antigens expressed heterogeneously within a tumor where ADCs with local bystander activity ${ }^{42,43}$ may be particularly be essentially desirable. The linker should be suitably stable in 
circulation to facilitate the long circulating half-life of the MAb and yet release active drug following antigenmediated internalization. Linkers can be broadly classified on the basis of their mechanism of drug release. Cleavable linkers release drug by hydrolysis or enzymatic cleavage following internalization whereas non-cleavable linkers, release drug via degradation of the $\mathrm{MAb}$ into lysosomes following antigen-specific internalization ${ }^{17,44-47}$. In addition to the mechanism of drug release, the specific site of conjugation, the potency of the drug and the average number of drug molecules per antibody needs to be carefully considered in the selection of the linker. Early ADCs incorporated drugs such as methotrexate ${ }^{48-50}$, vinblastine ${ }^{51,52}$ and doxorubicin ${ }^{11,18,53,54}$ each of which had displayed clinical activity as free drugs. In general these ADCs have demonstrated antigen-specific activity in vitro and in vivo but they required high dose levels of $\mathrm{ADC}$ to achieve substantial and appreciable antitumor activity. A variety of approaches have been evaluated to increase the potency of these ADCs including increasing the quantity of drug delivered per MAb. In the case of doxorubicin conjugates, increasing the drug:MAb ratio over a range of 1-25 molecules of drug/MAb was achieved by direct conjugation ${ }^{55}$, the use of branched linkers ${ }^{56,57}$ or polymeric carriers ${ }^{58}$.

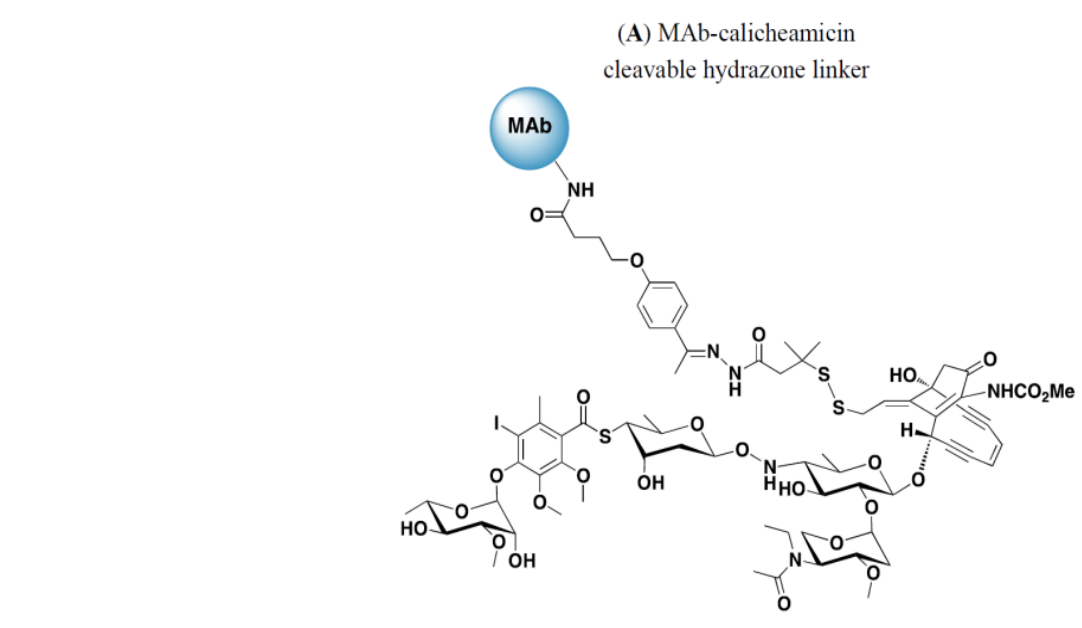

(B) MAb-monomethyl auristatin E

cleavable dipeptide (valine citrulline) linker

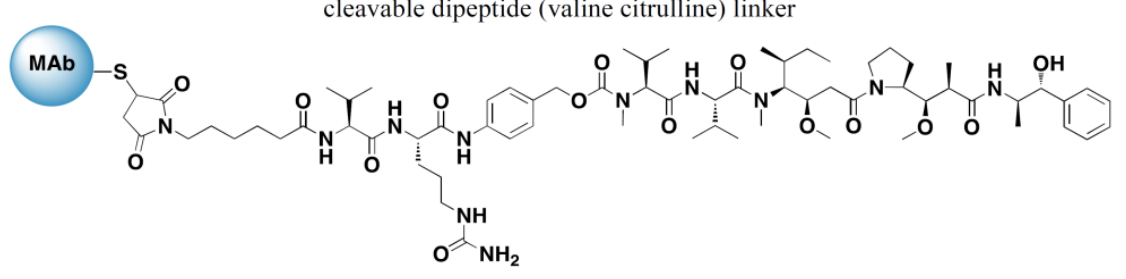

(D) MAb-Maytansine DM1

(C) MAb-Monomethyl auristatin F non-cleavable thioether linker

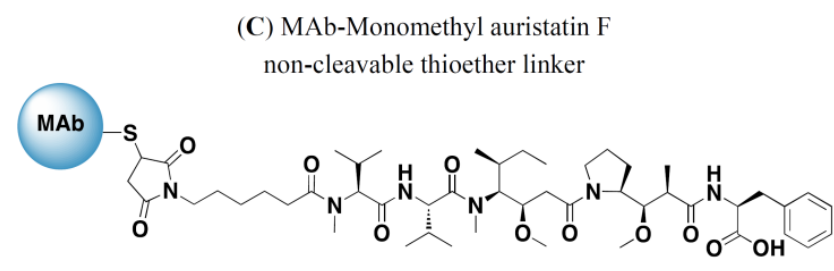

(E) MAb-Maytansine DM1 cleavable disulfide linker

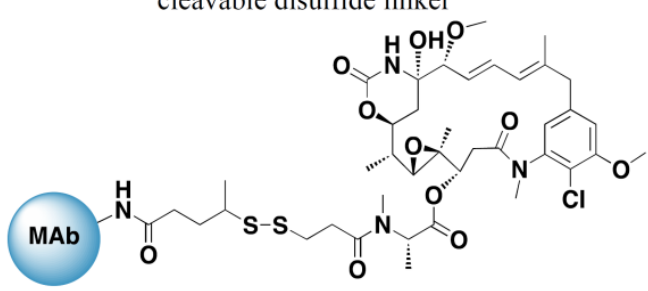

non-cleavable thioether linker

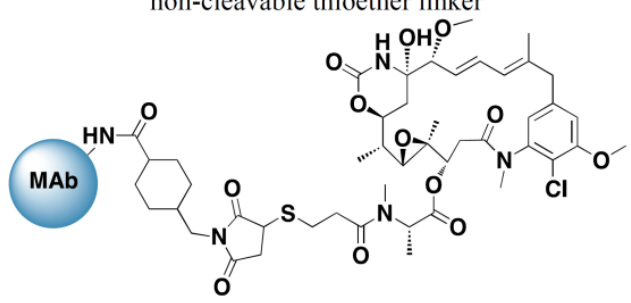

(F) MAb-Maytansine DM4

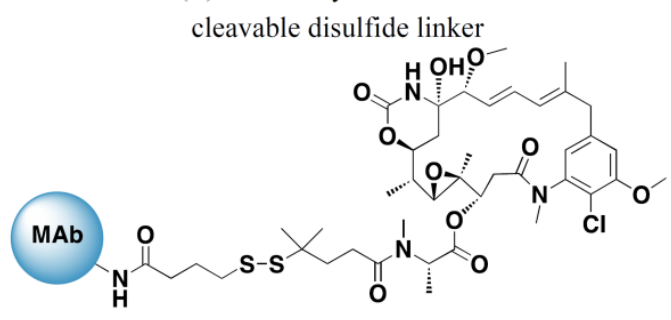

Figure 3: Various Linkers used in Antibody Drug Conjugates, (A)- MAb calicheamicin cleavable hydrazone linker; (B)- MAb-monomethyl auristatin E cleavable dipeptide (valine citrulline) linker; (C)- MAb-Monomethyl auristatins F non-cleavable thioether linker; (D)-MAb Maytansine DM1 non-cleavable thioether linker; (E)- MAb Maytansine DM1 cleavable disulfide linker; (F)-MAb Maytansine DM4 cleavable disulfide linker. 
Table 2: Antibody Drug Conjugates in Clinical Development

\begin{tabular}{|c|c|c|c|}
\hline $\begin{array}{l}\text { Candidate } \\
\text { (Target Antigen) }\end{array}$ & $\begin{array}{l}\text { Antibody-Drug Conjugate } \\
\text { [Mab]-[Linker]-[Drug] }\end{array}$ & Oncology Indication & Developer \\
\hline \multicolumn{4}{|c|}{ Phase Ill of clinical development } \\
\hline $\begin{array}{l}\text { Inotuzumab ozogamicin } \\
\text { (CD22) }\end{array}$ & [Hz IgG4]-[Hydrazone]-[Calicheamicin] & NHL & Pfizer \\
\hline $\begin{array}{l}\text { Gemtuzumab } \\
\text { ozogamicin } \\
\text { (CD33) }\end{array}$ & [Hz IgG4]-[Hydrazone]-[Calicheamicin] & $\begin{array}{l}\text { Relapsed } \\
\text { AML }\end{array}$ & Pfizer \\
\hline \multicolumn{4}{|c|}{ Phase ll of clinical development } \\
\hline $\begin{array}{l}\text { Lorvotuzumab } \\
\text { mertansine } \\
\text { (CD56) }\end{array}$ & [Hz IgG1] - [SPP] - [Maytansine DM1] & Solid Tumours,MM & ImmunoGen \\
\hline $\begin{array}{l}\text { Glembatumumab } \\
\text { vedotin } \\
\text { (GPNMB) }\end{array}$ & $\begin{array}{l}\text { [Hu IgG2] - [Valine-citrulline] - [Auristatin } \\
\text { MMAE] }\end{array}$ & $\begin{array}{l}\text { Breast Cancer, } \\
\text { Melanoma }\end{array}$ & $\begin{array}{l}\text { Celldex } \\
\text { Therapeutics }\end{array}$ \\
\hline $\begin{array}{l}\text { SAR-3419 } \\
(\mathrm{CD} 19)\end{array}$ & [Hz IgG1] - [SPDB] - [Maytansine DM4] & NHL & Sanofi \\
\hline $\begin{array}{l}\text { PSMA ADC } \\
\text { (PSMA) }\end{array}$ & $\begin{array}{l}\text { [Hu IgG1] -[Valine-Citruline]- [Auristatin } \\
\text { MMAE] }\end{array}$ & Prostate Cancer & Progenics \\
\hline $\begin{array}{l}\text { RG7593/DCDT2980S } \\
\text { (CD22) }\end{array}$ & $\begin{array}{l}\text { [Hz IgG1] - [Valine-Citruline]- [Auristatin } \\
\text { MMAE] }\end{array}$ & NHL & $\begin{array}{l}\text { Genentech } \\
\text { Roche }\end{array}$ \\
\hline $\begin{array}{l}\text { RG-7596 } \\
\text { (CD79b) }\end{array}$ & $\begin{array}{l}\text { [Hz IgG1] -[Valine-Cituline] - [Auristatin } \\
\text { MMAE] }\end{array}$ & NHL & $\begin{array}{l}\text { Genentech } \\
\text { Roche }\end{array}$ \\
\hline $\begin{array}{l}\text { BT-062 } \\
\text { (CD138) }\end{array}$ & [Ch IgG4] - [SPDB] - [Maytansine DM4] & MM & Biotest \\
\hline \multicolumn{4}{|c|}{ Phase I of clinical development } \\
\hline $\begin{array}{l}\text { SGN-75 } \\
(\text { CD70) }\end{array}$ & $\begin{array}{l}\text { [Hz IgG1] -[Malemidocaproyl] -[Auristatin } \\
\text { MMAF] }\end{array}$ & NHL,RCC & $\begin{array}{l}\text { Seattle } \\
\text { Genetics }\end{array}$ \\
\hline $\begin{array}{l}\text { BAY 79-4620 } \\
\text { (CA-IX) }\end{array}$ & $\begin{array}{l}\text { [Hu IgG1]-[Valine-citruline]-[auristatin } \\
\text { MMAE] }\end{array}$ & Solid Tumours & Bayer \\
\hline $\begin{array}{l}\text { Milatuzumab } \\
\text { doxorubicin } \\
\text { (CD74) }\end{array}$ & [Hz IgG1] -[Hydrazone]- [Doxorubicin] & MM & Immunomedics \\
\hline $\begin{array}{l}\text { AGS-5ME } \\
\text { (SLC44A4) }\end{array}$ & $\begin{array}{l}\text { [Hu IgG2] -[Valine-Citruline]-[Ausistatin } \\
\text { MMAE] }\end{array}$ & $\begin{array}{l}\text { Pancreatic, Prostate } \\
\text { Cancer }\end{array}$ & Astellas \\
\hline $\begin{array}{l}\text { BAY 94-9343 } \\
\text { (Mesothelin) }\end{array}$ & [Hu IgG1] - [SPDB]-[Maytansine DM4] & Solid Tumuors & Bayer \\
\hline $\begin{array}{l}\text { ASG-22ME } \\
\text { (Nectin-4) }\end{array}$ & $\begin{array}{l}\text { [Hu IgG1] -[Valine-Citruline] -[Auristatin } \\
\text { MMAE] }\end{array}$ & Solid Tumours & Astellas \\
\hline
\end{tabular}

\section{PREPARATION OF ANTIBODY DRUG CONJUGATES (ADC'S)}

Figure 4 displays a generic process overview of various process steps involved in ADC manufacturing using a non-cleavable Succinimidyl-4-(N-maleimidomethyl) cyclohexan-1-1carboxylate (SMCC) linker. The Succinimidyl-4- (N-maleimidomethyl) cyclohexan-1carboxylate (SMCC) linker is an amine-to-sulfhdryl crosslinker that comprises of NHS-ester and maleimide reactive groups located at opposite ends of a cyclohexanstabilized spacer arm. The NHS esters react with the primary amines at $\mathrm{pH}$ 7-9 to form suitable stable amide bonds. Maleimide reacts with sulhydryl groups at a $\mathrm{pH}$ of $6.5-7.5$ to form stable thioether bonds. The maleimide group of SMCC is stable up to $\mathrm{pH} 7.5$ because of the presence of cyclohexane bridge in the spacer arm ${ }^{59,60}$.

ADC production process utilizing the SMCC linker is characterized by steps which involve controlling the antibody modification (preparing the antibody for the conjugation reaction) and conjugation reaction (introduction of drug moiety) employed to achieve the desired level of drug loading. The molar ratio of drug to antibody can be adjusted by changing the reaction stoichiometry to deliver the desired level of potency to the target tissue ${ }^{61}$. Additional steps such as removal of process related contamination, concentration of the 
active pharmaceutical ingredient (API) and stabilization of the resulting bulk drug substance (BDS) are also critical steps in the manufacturing process.

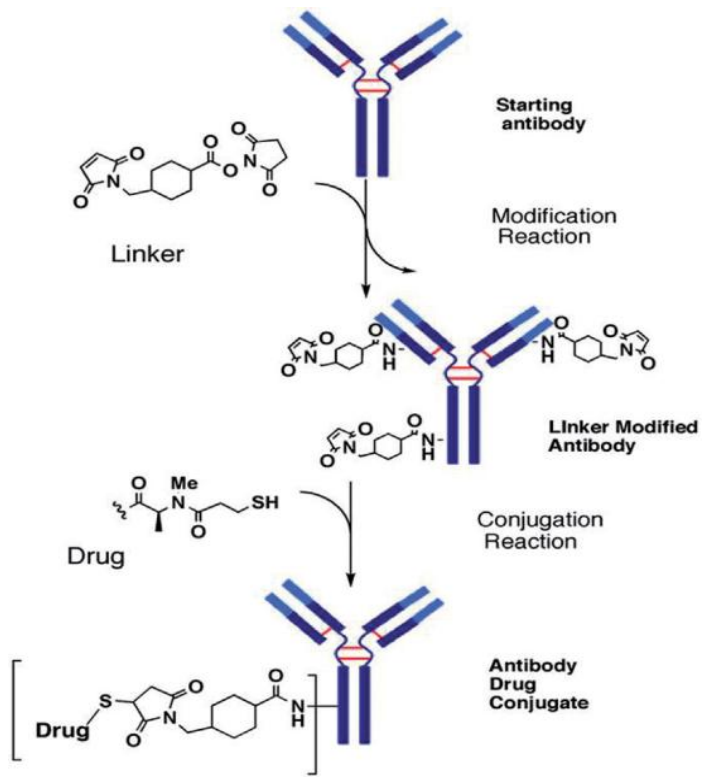

Figure 4: ADC Prepartion Process using noncleavable Succinimidyl-4-(N-maleimidomethyl) cyclohexan-1-1carboxylate (SMCC) linker.

\section{REGULATORY ASPECTS}

In order to develop and characterize the ADC certain analytical methods must be implemented in order to verify and identify the type of MAb and cytotoxic drug to be used in its manufacture ${ }^{62}$. These analytical techniques are used for the characterization of the ADC and may include protein mass spectrometry (PMS) and capillary electrophoresis (CE). A wide range of analytical tools can be effectively employed to determine the molecular weight of the ADC including peptide mapping and sequencing. The structure and linkage of the linker-drug combination can further be determined and analyzed using multi-NMR ${ }^{63}$ and FTIR spectroscopic techniques ${ }^{64}$. X-Ray crystallography can further be used to assess and examine the peptide or antibody structure and the drug to antibody ratio (DAR) can be suitably evaluated using UV methods 65 . Subsequently, the application of size-exclusion chromatography (SEC) techniques can be used to determine fragmentation pattern and aggregate patterns during the synthesis of the ADC ${ }^{66}$. Furthermore, the antigen binding and biological activity of the MAbs must also be assessed against ELISA, in vitro cell-based assays and in vivo studies ${ }^{67}$. A critical factor which needs attention is to develop robust analytical methods to determine the level of free cytotoxic drug ${ }^{68}$. In addition, chemical impurities obtained during the synthesis which include the impurity profile from host cell proteins must also be identified and characterized ${ }^{69}$. The manufactured ADC must be evaluated as a new molecular entity and not as a separate product (antibody-linker-drug). This is to elucidate a structure/function relationship towards: the pharmacokinetics profile and low immunogenicity; the cytotoxic drug must demonstrate potent anti-tumour activity; linker has to be stable so as to enable the delivery of the ADC to target antigen; MAb must have high affinity and selectivity towards the cellular targets. The tumour-associated antigen expression ratio must be significantly high in tumours in comparison to normal tissue and must allow the ADC-antigen complex to be internalized

Table 3: Merits \& De-merits of ADC therapy

\begin{tabular}{|c|c|}
\hline Merits of ADC Therapy & De-merits of ADC Therapy \\
\hline $\begin{array}{l}\text { Selective delivery of cytotoxic drugs to } \\
\text { tumour cells }\end{array}$ & $\begin{array}{c}\text { Molecular targets having similar expression may also get exposed to } \\
\text { the dug leading to toxicity }\end{array}$ \\
\hline Specific binding to target antigen & Requires screening of antigen of interest \\
\hline Large therapeutic index & Premature release of cytotoxic drug may lead to lethal effects \\
\hline $\begin{array}{l}\text { Stability of conjugate ensures extended and } \\
\text { prolonged circulation half life }\end{array}$ & Sufficient concentration may not be achieved at target site \\
\hline Reduction of adverse effects & Heterogeneous antigen expression can hamper the desired results \\
\hline
\end{tabular}
(Source: Beverly A.Teicher; Ravi V.J. Chari; Clin Cancer Res; 2011; 17(20); 6389-97.)

\section{PRESENT AND FUTURE OF ADC'S}

Currently, there are 2 ADCs available for patients in the United States. However, with more than about 30 additional molecules under clinical trials (Table 2), it is very likely that number of approved ADCs will enhance substantially in the coming decade. Moreover, this class of drugs provides a new opportunity to re-examine the future and potentially safe cytotoxic therapy. The combination of improved and enhanced potency with better tolerability profile offers the ray of hope for curing more life threatening cancers and, for those cancers that cannot be totally eradicated, ensuring an extended therapy and an improved quality of life for these patients. A century after Paul Ehrlich, his challenge has been taken up by a new generation of scientists who are working deligently to improve the specificity and activity of cancer chemotherapy. Although ADCs have just recently come up in the scenario, the evolution of the field is rapidly accelerating and the impact on cancer care is likely to be great in the years to come. 


\section{REFERENCES}

1. Kohler, G.; Milstein, C. Continuous cultures of fused cells secreting antibody of pre defined specificity. Nature 1975, 256, 495-497.

2. Carter, P.J. Potent antibody therapeutics by design. Nat. Rev. Immunol. 2006, 6, 343-357.

3. Jakobovits, A. The long-awaited magic bullets: Therapeutic human monoclonal antibodies from transgenic mice. Expert Opin. Investig. Drugs 1998, 7, 607-614.

4. Lonberg, N. Human antibodies from transgenic animals. Nat. Biotechnol. 2005, 23, 1117- 1125 .

5. Reichert, J.M.; Dhimolea, E. The future of antibodies as cancer drugs. Drug Discov. Today. 2012, 17, 954-963.

6. Goldenberg, D.M.; Sharkey, R.M. Radioactive antibodies: A historical review of selective targeting and treatment of cancer. Hosp. Pract. (Minneap) 2010, 38, 82-93.

7. Steiner, M.; Neri, D. Antibody-radionuclide conjugates for cancer therapy: Historical considerations and new trends. Clin. Cancer Res. 2011, 17, 6406-6416.

8. Weldon, J.E.; Pastan, I. A guide to taming a toxinRecombinant immunotoxins constructed from pseudomonas exotoxin A for the treatment of cancer. FEBS J. 2011, 278, 4683-4700.

9. Lorberboum-Galski, H. Human toxin-based recombinant immunotoxins/chimeric proteins as a drug delivery system for targeted treatment of human diseases. Expert Opin. Drug Deliv. 2011, 8, 605-621.

10. Choudhary, S.; Mathew, M.; Verma, R.S. Therapeutic potential of anticancer immunotoxins. Drug Discov. Today 2011, 16, 495-503.

11. Trail, P.A.; Willner, D.; Lasch, S.J.; Henderson, A.J.; Hofstead, S.; Casazza, A.M.; Firestone, R.A.; Hellstrom, I.; Hellstrom, K.E. Cure of xenografted human carcinomas by BR96, doxorubicin immunoconjugates. Science 1993, 261, 212-215.

12. Hinman, L.M.; Hamann, P.R.; Wallace, R.; Menendez, A.T.; Durr, F.E.; Upeslacis, J. Preparation and characterization of monoclonal antibody conjugates of the calicheamicins: A novel and potent family of antitumor antibiotics. Cancer Res. 1993, 53, 3336-3342.

13. Liu, C.; Chari, R.V. The development of antibody delivery systems to target cancer with highly potent maytansinoids. Expert Opin. Investig. Drugs 1997, 6, 169-172.

14. Doronina, S.O.; Toki, B.E.; Torgov, M.Y.; Mendelsohn, B.A.; Cerveny, C.G.; Chace, D.F.; DeBlanc, R.L.; Gearing, R.P.; Bovee, T.D.; Siegall, C.B.; et al. Development of potent monoclonal antibody auristatin conjugates for cancer therapy. Nat. Biotechnol. 2003, 21, 778-784.

15. Trail, P.A.; Bianchi, A.B. Monoclonal antibody drug conjugates in the treatment of cancer. Curr. Opin. Immunol. 1999, 11, 584-588.

16. Dubowchik, G.M.; Walker, M.A. Receptor-mediated and enzyme-dependent targeting of cytotoxic anticancer drugs. Pharmacol. Ther. 1999, 83, 67-123.

17. Dubowchik, G.M.; Firestone, R.A.; Padilla, L.; Willner, D.; Hofstead, S.J.; Mosure, K.; Knipe, J.O.; Lasch, S.J.; Trail, P.A. Cathepsin B-labile dipeptide linkers for lysosomal release of doxorubicin from internalizing immunoconjugates: Model studies of enzymatic drug release and antigen-specific in vitro anticancer activity. Bioconjug. Chem. 2002, 13, 855-869.

18. Trail, P.A.; King, H.D.; Dubowchik, G.M. Monoclonal antibody drug immunoconjugates for targeted treatment of cancer. Cancer Immunol. Immunother. 2003, 52, 328-337.

19. Teicher, B.A. Antibody-drug conjugate targets. Curr. Cancer Drug Targets 2009, 9, 982-1004.

20. Blanc, V.; Bousseau, A.; Caron, A.; Carrez, C.; Lutz, R.J.; Lambert, J.M. SAR3419: An anti- CD19-maytansinoid immunoconjugate for the treatment of B-cell malignancies. Clin. Cancer Res. 2011, 17, 6448-6458.

21. Lewis Phillips, G.D.; Li, G.; Dugger, D.L.; Crocker, L.M.; Parsons, K.L.; Mai, E.; Blattler, W.A.; Lambert, J.M.; Chari, R.V.; Lutz, R.J.; et al. Targeting HER2-positive breast cancer with trastuzumab-DM1, an antibody-cytotoxic drug conjugate. Cancer Res. 2008, 68, 9280-9290.
22. Petrul, H.M.; Schatz, C.A.; Kopitz, C.C.; Adnane, L.; McCabe, T.J.; Trail, P.; Ha, S.; Chang, Y.S.; Voznesensky, A.; Ranges, G.; et al. Therapeutic mechanism and efficacy of the antibody drug conjugate BAY 79-4620 targeting human carbonic anhydrase 9. Mol.Cancer Ther. 2012, 11, 340-349.

23. Wahl, A.F.; Klussman, K.; Thompson, J.D.; Chen, J.H.; Francisco, L.V.; Risdon, G.; Chace, D.F.; Siegall, C.B.; Francisco, J.A. The anti-CD30 monoclonal antibody SGN-30 promotes growth arrest and DNA fragmentation in vitro and affects antitumor activity in models of Hodgkin's disease. Cancer Res. 2002, 62, 3736-3742.

24. Barginear, M.F.; John, V.; Budman, D.R. Trastuzumab-DM1: A clinical update of the novel antibody-drug conjugate for HER2-overexpressing breast cancer. Mol. Med. 2012, 18, 1473-1479.

25. Ogura, M.; Hatake, K.; Ando, K.; Tobinai, K.; Tokushige, K.; Ono, C.; Ishibashi, T.; Vandendries, E. Phase I study of antiCD22 immunoconjugate inotuzumab ozogamicin plus rituximab in relapsed/refractory B-cell non-Hodgkin lymphoma. Cancer Sci. 2012, 103, 933-938.

26. Ricart, A.D. Antibody-drug conjugates of calicheamicin derivative: gemtuzumab ozogamicin and inotuzumab ozogamicin. Clin. Cancer Res. 2011, 17, 6417-6427.

27. Verma, S.; Miles, D.; Gianni, L.; Krop, I.E.; Welslau, M.; Baselga, J.; Pegram, M.; Oh, D.Y.; Dieras, V.; Guardino, E. Trastuzumab emtansine for HER2-positive advanced breast cancer. N. Engl. J. Med. 2012, 367, 1783-1791.

28. Younes, A.; Bartlett, N.L.; Leonard, J.P.; Kennedy, D.A.; Lynch, C.M.; Sievers, E.L.; Forero- Torres, A. Brentuximab vedotin (SGN-35) for relapsed CD30-positive lymphomas. N. Engl. J. Med. 2010, 363, 1812-1821.

29. Younes, A.; Kim, S.; Romaguera, J.; Copeland, A.; Farial Sde, C.; Kwak, L.W.; Fayad, L.;Hagemeister, F.; Fanale, M.; Neelapu, S. Phase I multidose-escalation study of the antiCD19 maytansinoid immunoconjugate SAR3419 administered by intravenous infusion every 3 weeks to patients with relapsed/refractory B-cell lymphoma. J. Clin. Oncol. 2012, 30, 2776-2782

30. Krall N, Scheuermann J, Neri D. Small targeted cytotoxics: current state and promises from DNA-encoded chemical libraries. Angew Chem Int Ed Engl. 2013;52(5):1384-1402.

31. Scott AM, Wolchok JD, Old LJ. Antibody therapy of cancer. Nat Rev Cancer. 2012;12(4):278-287.

32. Wu AM, Senter PD. Arming antibodies: prospects and challenges for immunoconjugates. Nat Biotechnol. 2005;23(9):1137- 1146.

33. Sievers EL, Senter PD. Antibody-drug conjugates in cancer therapy. Annu Rev Med. 2013;64:15-29.

34. Carter PJ, Senter PD. Antibody-drug conjugates for cancer therapy. Cancer J. 2008;14(3):154-169.

35. Teicher BA, Chari RV. Antibody conjugate therapeutics: challenges and potential. Clin Cancer Res. 2011;17(20):63896397.

36. Teicher B.A., Curr. Cancer Drug Targets, 2009; 9, 982-1004.

37. Senter PD., Curr. Opinion in Chemical Biology, 2009 13, 235 244.

38. Ritchie M., Tchistiakova L., Nathan S., MAbs, 2013;5(1), 1321.

39. Ricart A.D., Clin. Cancer Res., 2011;17, 6417-6427.

40. Dumontet C., Jordan M.A., Nat. Rev. Drug Discov.,2010; 9, 790-803.

41. Schrama D., Reisfeld R.A., Becker J.C., Nat. Rev. Drug Discov.,2006; 5, 147-159.

42. Kovtun, Y.V.; Goldmacher, V.S. Cell killing by antibody-drug conjugates. Cancer Lett. 2007, 255, 232-240.

43. Okeley, N.M.; Miyamoto, J.B.; Zhang, X.; Sanderson, R.J.; Benjamin, D.R.; Sievers, E.L.; Senter, P.D.; Alley, S.C. Intracellular activation of SGN-35, a potent anti-CD30 antibody-drug conjugate. Clin. Cancer Res. 2010, 16, 888-897.

44. Chari, R.V. Targeted cancer therapy: Conferring specificity to cytotoxic drugs. Acc. Chem. Res.2008, 41, 98-107.

45. Doronina, S.O.; Bovee, T.D.; Meyer, D.W.; Miyamoto, J.B.; Anderson, M.E.; Morris-Tilden, C.A.; Senter, P.D. Novel 
peptide linkers for highly potent antibody-auristatin conjugate. Bioconjug. Chem. 2008, 19, 1960-1963.

46. Dubowchik, G.M.; Radia, S.; Mastalerz, H.; Walker, M.A.; Firestone, R.A.; Dalton King, H.; Hofstead, S.J.; Willner, D.; Lasch, S.J.; Trail, P.A. Doxorubicin immunoconjugates containing bivalent, lysosomally-cleavable dipeptide linkages. Bioorg. Med. Chem. Lett. 2002, 12, 1529-1532.

47. Zhao, R.Y.; Wilhelm, S.D.; Audette, C.; Jones, G.; Leece, B.A.; Lazar, A.C.; Goldmacher, V.S.;Singh, R.; Kovtun, Y.; Widdison, W.C.; et al. Synthesis and evaluation of hydrophilic linkers for antibody-maytansinoid conjugates. J. Med. Chem. 2011, 54, 3606-3623.

48. Smyth, M.J.; Pietersz, G.A.; McKenzie, I.F. The mode of action of methotrexate-monoclonal antibody conjugates. Immunol. Cell Biol. 1987, 65, 189-200.

49. Ghose, T.; Ferrone, S.; Blair, A.H.; Kralovec, Y.; Temponi, M.; Singh, M.; Mammen, M.Regression of human melanoma xenografts in nude mice injected with methotrexate linked to monoclonal antibody 225.28 to human high molecular weight melanoma associated antigen.Cancer Immunol. Immunother. 1991, 34, 90-96.

50. Elias, D.J.; Kline, L.E.; Robbins, B.A.; Johnson, H.C., Jr.; Pekny, K.; Benz, M.; Robb, J.A.;Walker, L.E.; Kosty, M.; Dillman, R.O. Monoclonal antibody KS1/4-methotrexate immunoconjugate studies in non-small cell lung carcinoma. Am. J. Respir. Crit. Care Med. b1994, 150, 1114-1122

51. Schrappe, M.; Bumol, T.F.; Apelgren, L.D.; Briggs, S.L.; Koppel, G.A.; Markowitz, D.D.; Mueller, B.M.; Reisfeld, R.A. Long-term growth suppression of human glioma xenografts by chemoimmunoconjugates of 4-desacetylvinblastine-3carboxyhydrazide and monoclonal antibody 9.2.27. Cancer Res. 1992, 52, 3838-3844.

52. Petersen, B.H.; DeHerdt, S.V.; Schneck, D.W.; Bumol, T.F. The human immune response to KS1/4-desacetylvinblastine (ly256787) and KS1/4-desacetylvinblastine hydrazide (LY203728) in single and multiple dose clinical studies. Cancer Res. 1991, 51, 2286-2290.

53. Yang, H.M.; Reisfeld, R.A. Doxorubicin conjugated with a monoclonal antibody directed to a human melanomaassociated proteoglycan suppresses the growth of established tumor xenografts in nude mice. Proc. Natl. Acad. Sci. USA $1988,85,1189-1193$

54. Shih, L.B.; Goldenberg, D.M.; Xuan, H.; Lu, H.W.; Mattes, M.J.; Hall, T.C. Internalization of an intact doxorubicin immunoconjugate. Cancer Immunol. Immunother. 1994, 38, 92-98.

55. Trail, P.A.; Willner, D.; Lasch, S.J.; Henderson, A.J.; Greenfield, R.S.; King, D.; Zoeckler, M.E.; Braslawsky, G.R. Antigen-specific activity of carcinoma-reactive BR64doxorubicin conjugates evaluated in vitro and in human tumor xenograft models. Cancer Res. 1992, 52, 5693-5700.

56. King, H.D.; Yurgaitis, D.; Willner, D.; Firestone, R.A.; Yang, M.B.; Lasch, S.J.; Hellstrom, K.E.; Trail, P.A. Monoclonal antibody conjugates of doxorubicin prepared with branched linkers: A novel method for increasing the potency of doxorubicin immunoconjugates. Bioconjug. Chem. 1999, 10, 279-288.

57. King, H.D.; Dubowchik, G.M.; Mastalerz, H.; Willner, D.; Hofstead, S.J.; Firestone, R.A.; Lasch, S.J.; Trail, P.A. Monoclonal antibody conjugates of doxorubicin prepared with branched peptide linkers: Inhibition of aggregation by methoxytriethyleneglycol chains. J. Med. Chem. 2002, 45, 4336-4343.

58. Shih, L.B.; Goldenberg, D.M.; Xuan, H.; Lu, H.; Sharkey, R.M.; Hall, T.C. Anthracycline immunoconjugates prepared by a site-specific linkage via an amino-dextran intermediate carrier.Cancer Res. 1991, 51, 4192-4198.

59. C. Bieniarz., Bioconjug. Chem.,1996,7, 88-95.

60. M.D. Partis., J. Protein. Chem.,1983, 2, 263-277.

61. L. Ducry, B. Stump, Bioconjug. Chem.,2010, 21, 5-13.

62. Harris J., Jacobson J., Jochheim C., Amphlett G., Francissen K., McLeod L., Bioprocess Int.,2011, 9(8), 12-22

63. Betz Marco., Saxena K., Schwalbe H., Curr. Opin. Chem. Biol; 2006, 10(3), 219-225.

64. Scott C., BioProcess Int.,2010, 8(10).

65. Wakankar A., Chen Y., Gokarn Y., Jacobson F.S., MAbs.,2011,3(2), 161-172.

66. Hong P., Koza S., Bouvier E.S., J. Liq. Chromatogr. Relat. Technol.,2012, 35(20), 2923- 2950.

67. Hoogenboom H.R., Nat. Biotechnol.,2005, 23(8), 1105-1116.

68. Vainchtein L.D., Rosing H., Schellens J.H.M., Beijnen J.H.,2008, Open Anal. Chem. J., 2, 10-39.

69. Jin M., Szapiel N., Zhang J., Hickey J., Ghose S.,2010, Biotechnol. Bioeng., 105(2), 306-316.

70. Girish, S., Gupta M., Wang B., Lu D., Krop I.E., Vogel C.L.,2012, Cancer Chemother. Pharmacol., 69(5), 12291240. 